Bull. Fac.Agric.,Cairo Univ., 63: 327-332 (2012).

\title{
EFFECT OF STREPTOMYCIN SULPHATE AND CHLORAMPHENICOL SODIUM SUCCINATE ON IMMUNE RESPONSE
}

(Received: 14.6.2012)

\author{
By \\ M. Z. Sedik, W. D. Saleh, S. A. Said and M. H. Mohamed \\ Microbiology Department, Faculty of Agriculture, Cairo University, Giza, Egypt
}

\begin{abstract}
Streptomycin and chloramphenicol are antibiotic drugs.Streptomycin is the first of a class of drugs called aminoglycosides to be discovered, as well as was the first antibiotic used for tuberculosis. It is derived from the actinobacterium Streptomyces griseus. Moreover, chloramphenicol was originally produced by Streptomyces venezuelae. It is considered a prototypical broad-spectrum antibiotic, alongside the tetracycline's. Because both antibiotics are cheap and easy to manufacture, they are frequently found as a drug of choice in the third world.

Streptomycin Sulphate $(100 \mathrm{mg} / \mathrm{kg})$ and chloramphenicol SodiumSuccinate $(200 \mathrm{mg} / \mathrm{kg})$, were used to study their effect on immune response by measuring different immune parameters like total WBC's and total globulin. Bacterial antigens applied in this study were two bacterial strains (Bacillus spp. and Pseudomonas spp.).The results obtained indicated that, there was a change in various data record, which means there was a suppression in the immune response of the body .
\end{abstract}

Key words: antibiotics, chloramphenicol, immune response, streptomycin.

\section{INTRODUCTION}

The immune system is known to be involved in the etiology and pathophysiological mechanism of several diseases (Chirigos, 1992 and Dale, et al., 1994). The function and efficiency of the immune system may be influenced by many exogenous and endogenous factors resulting in either immunosuppression or immunostimulation (De Weck, 1990). Antibiotics are natural substances suppressing bacterial growth. Pharmacological action is successfully used in treatment of infections which threaten people. Some types of antibiotics provide anti-inflammatory action. They are substances, attacking microbial, animal or vegetative cells suppressing microorganism growth. Antibiotics are used in treatment of different diseases caused by microorganisms and bacteria. For treatment of other diseases, there are many other medications, effective and safe. There are a huge number of various antibiotics characterized by specific features, but in general provide the same pharmacological action and as a rule, indicated in treatment of different diseases. Dewdeny (1977) and Sheng, et al. (1987) reported that various antibiotics interfere with immune response. Antibiotics like clindamycin and netilmycin administered at therapeutic doses to mice caused a significant inhibition of phagocytosis. On the other hand, lomefloxacin, ofloxacin and cipropfloxacin had no effect on immune response (Iordanova, et al., 1995, Iordanova, et al.,1996 and Jayakumar, et al., 2002). Streptomycin is a protein synthesis inhibitor. It binds to the small 16S rRNA of the 30S subunit of the bacterial ribosome, interfering with the binding of formyl-methionyl-tRNA to the $30 \mathrm{~S}$ subunit. This leads to codon misreading, eventual inhibition of protein synthesis and ultimately death of microbial cells through mechanisms that are still not understood (Sharma, et al., 2007). Also, Neu and Gootz, (1996) said that Chloramphenicol has a very broad spectrum of activity as it acts by inhibiting bacterial protein synthesis.

This study was concerned with studying of the effect of two antibiotics on immune response.

\section{MATERIALS AND METHODS}

\subsection{Antigenic organisms}

Sixty three bacterial isolates were isolated from soil samples, collected from the farm of the Faculty of Agriculture, Cairo University, Giza, Egypt. The isolates were purified and studied for morphological characteristics. Serial dilution aliquots were used for the inoculation of the culture media. Enrichment and isolation of the 
bacterial isolates were performed using Nutrient agar medium.

Plates were incubated for two to three days at $30^{\circ} \mathrm{C}$. Selective isolates were transferred to fresh media until identification and classification.

From the total purified isolates, thirteen were chosen according to their morphological characteristics and selected to test the antibiotic sensitivity.

Two bacterial strains (Bacillus spp. and Pseudomonas spp.) were chosen according to sensitivity test using Disc diffusion technique. Cultures were incubated at $30^{\circ} \mathrm{C}$ for $24-48 \mathrm{hrs}$. After incubation period, the zones of inhibition were measured for selection of the best bacterial strains to be used as bacterial antigen.

\subsection{Selection of antibiotic dose}

Antibiotic dose of each antibiotic was calculated on the basis of surface area ratio according to the calculation carried out by the formula of Mosteller (1987):

BSA $\left(\mathrm{m}^{2}\right)=([\text { Height }(\mathrm{cm}) \times \text { Weight }(\mathrm{kg})] / 3600)^{1 / 2}$

Where BSA is the body surface area.

\subsection{Experimental animals}

This experiment was carried out in the Microbiology and Biochemistry Departments, Faculty of Agriculture, Cairo University. Wistar rats used in this experiment were brought from the National Organization for Drug and Control Research. Rats were kept under standard laboratory conditions, where rats were housed in cages and fed standard rat chow and water.

The experiment was carried out in a Completely Randomized Design (CRD). Rats were divided into four groups, each contained three animals. Group I \& III were served as a control which received $0.5 \mathrm{ml}$ of antigen, of bacterial cells intramuscularly on the first day of the experiment. While,group II was administered with streptomycin sulphate at a dose of $100 \mathrm{mg} / \mathrm{kg}$ body weight, twice daily throughout a period of 14 days and $0.5 \mathrm{ml}$ of bacterial cells intramuscular (im) on the first day. Also,group IV was administrated with chloramphenicol sodiumsuccinate at a dose of $200 \mathrm{mg} / \mathrm{kg}$. Body weight was measured twice daily for a period of 14 days and $0.5 \mathrm{ml}$ of bacterial cells im on the first day.

\section{METHOD}

Both antibiotics (streptomycin sulphate and chloramphenicol sodium succinate), were injected to each rat group for 14 days. The blood samples were collected at $0,7^{\text {th }}$ and $14^{\text {th }}$ days according to Killby and Silverman (1967), then total WBC's and total globulin was calculated in the blood samples.

Total WBC's was measured by Haemocytometer method (Weber et al., 2002). In addition, total globulin was calculated by subtraction of total protein which was done according to the method carried out by Cannon (1974). While, albumin was calculated according to Doumas et al. (1971) and measured by colorimetric method using spectrophotometer Jenway (6300) UK.

\section{RESULTS AND DISCUSSION}

Fourty bacterial isolates ( $G+v e$ and $G$-ve ) of soil samples were obtained. The taxonomical studies of the isolates were carried out in the Microbiology Department, Faculty of Agriculture, Cairo University. From the data on these isolates, the results showed that they represented different genera. So that, thirteen isolates were chosen for studying the antibiotic sensitivity. Also these isolates represented four genera Bacillus spp. (five isolates),Pseudomonas spp. (four isolates), Lactobacillus spp. (one) and Actinomycetes spp.(three isolates).Based on the results obtained, we found that Bacillus spp. represents $38.4 \%$, Pseudomonas spp. represents $30.7 \%$, Lactobacillus spp. represents $23 \%$ and Actinomycetes spp. represents $7.6 \%$, of the total isolates.

The results on antibiotic sensitivity test indicated that, the inhibition zone diameter of bacterial isolates ranged between $1.2 \mathrm{~mm}$ and 3.8 $\mathrm{mm}$. Moreover, both of Bacillus spp. and Pseudomonas spp. gave the highest inhibition zone which gave $3.8 \mathrm{~mm}$ (Table 1).

Bacterial strains (Bacillus spp. and Pseudomonas spp.) were introduced as antigen in the Wistar rat in for 14 days. Results on blood samples which were collected at $0,7^{\text {th }}$ and $14^{\text {th }}$ days, showed a significant difference at $\mathrm{T} 0.05$ between treatments with antibiotic in short and long terms.

Firstly, the results on the effect of chloramphenicol sodium succinate (c) presented in Fig. (1) showed decrease in TWBC's at the $7^{\text {th }}$ and the $14^{\text {th }}$ day which means a decrease in immune response that is responsible for absorption of foreign organisms at short and long terms.

The obtained results on chloramphenicol treatment agree with the data recorded by many researches. These researchers mentioned that, the primary danger of chloramphenicol is that it suppresses the bone marrow. This is dangerous 
Table (1): Inhibition zone diameter of thirteen bacterial isolates.

\begin{tabular}{|c|c|c|c|}
\hline \multirow[b]{2}{*}{ Strain no. } & \multirow[b]{2}{*}{ Genera name } & \multicolumn{2}{|c|}{ Zone of inhibition diameter in $\mathrm{mm}$} \\
\hline & & $\begin{array}{c}\text { Streptomycin } \\
\text { sulphate }\end{array}$ & $\begin{array}{l}\text { Chloramphenicol } \\
\text { sodium succinate }\end{array}$ \\
\hline 1 & Bacillus spp. & 3.4 & 2.4 \\
\hline 2 & Pseudomonas spp. & 3.2 & 3.2 \\
\hline 3 & Bacillus spp. & 3.8 & 2.4 \\
\hline 4 & Pseudomonas spp. & 2.2 & 2.2 \\
\hline 5 & Bacillu sspp. & 2.8 & 2.6 \\
\hline 6 & Actinomycetes spp. & 2.2 & 1.2 \\
\hline 7 & Pseudomonas spp. & 2.8 & 3.8 \\
\hline 8 & Lactobacillus spp. & 2.1 & 1.8 \\
\hline 9 & Bacillus spp. & 2.3 & 2.2 \\
\hline 10 & Lactobacillus spp. & 2.6 & 2.4 \\
\hline 11 & Lactobacillus spp. & 2.6 & 1.3 \\
\hline 12 & Pseudomonas spp. & 2.7 & 2.9 \\
\hline 13 & Bacillus spp. & 2.8 & 2.1 \\
\hline
\end{tabular}

because the bone marrow is the site of the synthesis of new blood cells. Consequently, patients taking chloramphenicol may become deficient in platelets, as well as white and red blood cells. This can cause patients to bleed more easily, to be anaemic, and to have a weak end immune system (Neu, and Gootz, 1996). So, in the results the WBC's are proved to be really affected very dangerously as it decreased in its count at short and long terms treatment. (Fig.1). response was not recorded.The decrease in total globulin at $14^{\text {th }}$ day (long term), means that the antibodies formation was affected by chloramphenicol sodium succinate and so the immune response decreased (Fig.2).

Chloramphenicol sodium succinate didn't affect the total globulin at long term treatment, that means it did not interfere with globulin at short term, but, it suppressed globulin. at long term.

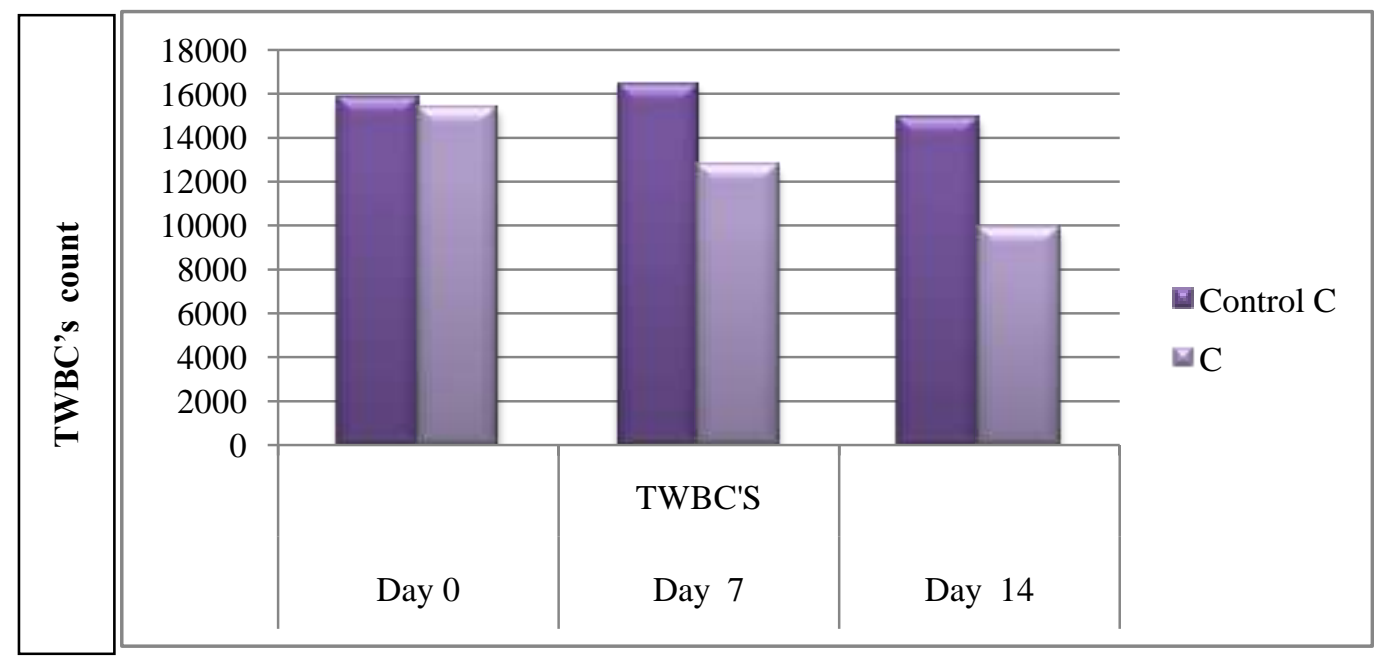

Fig. (1): Effect of chloramphenicol sodium succinate on TWBC's $\left(10^{3} / \mathrm{mm}^{3}\right)$

Data on the effect of chloramphenicol sodium succinate (c) on total globulin compared to the control (control c) at $0,7^{\text {th }} \& 14^{\text {th }}$ day, showed an increase in total globulin at the $7^{\text {th }}$ day (short term).This means that, antibodies formation is increased and not affected by chloramphenicol sodium succinate so any effect on immune
Data presented in Fig. (3) reveal that, of streptomycin sulphate (s) effect on TWBC's when compared to the control (control s) at the $0,7^{\text {th }}$ and $14^{\text {th }}$ day. The results show a decrease in TWBC's at the $7^{\text {th }}$ and $14^{\text {th }}$ day of experimental period that means a decrease in the immune response which is responsible for absorption of 


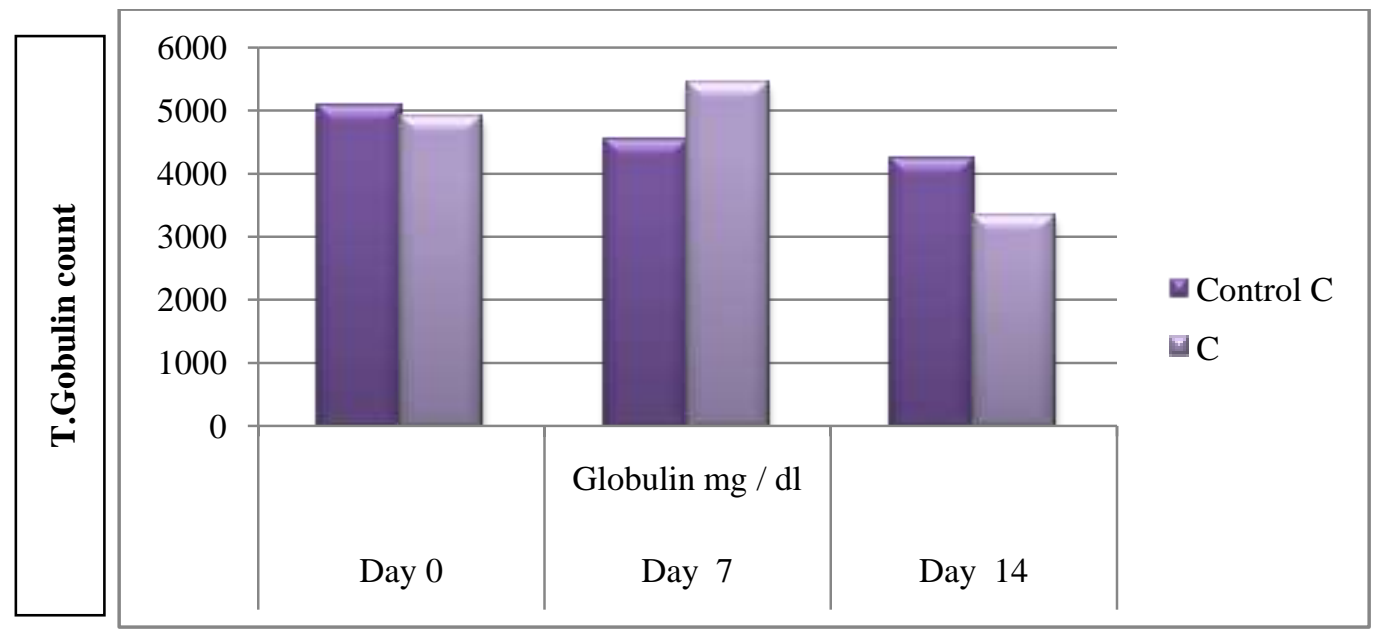

Fig. (2): Effect of chloramphenicol sodium succinate on total globulin.

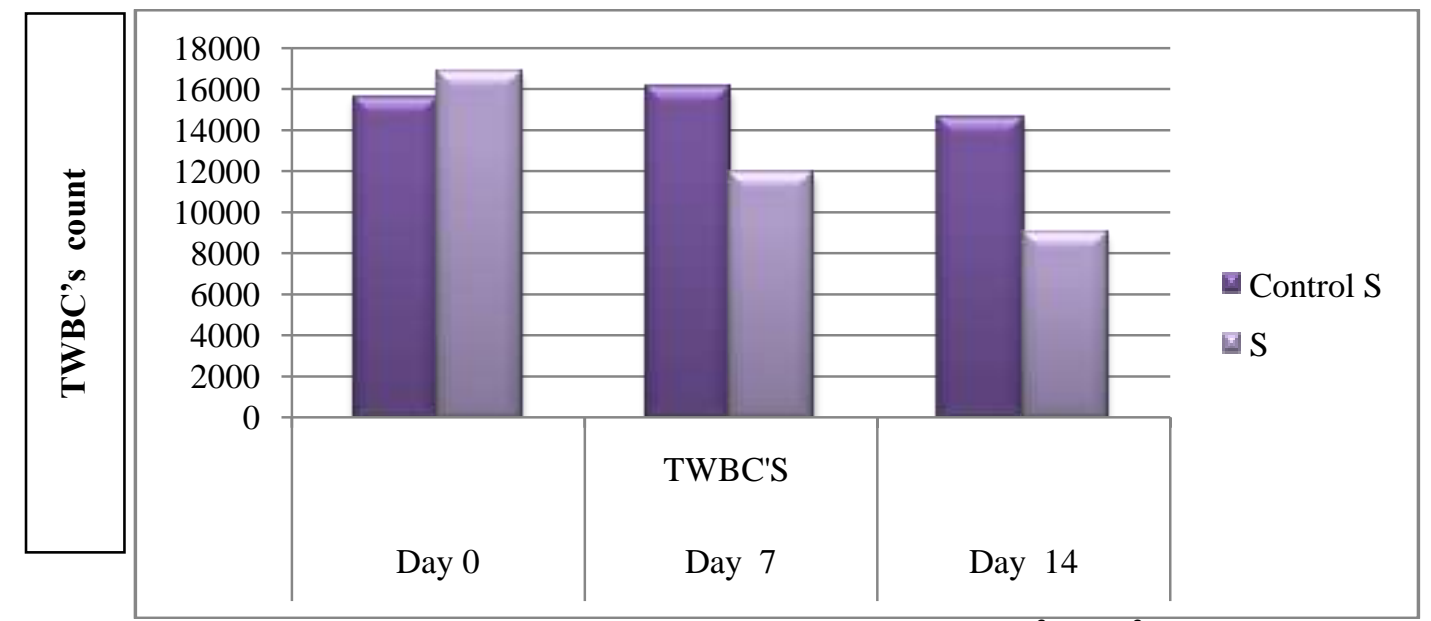

Fig. (3): Effect of streptomycin sulphate on TWBC's $\left(10^{3} / \mathrm{mm}^{3}\right)$.

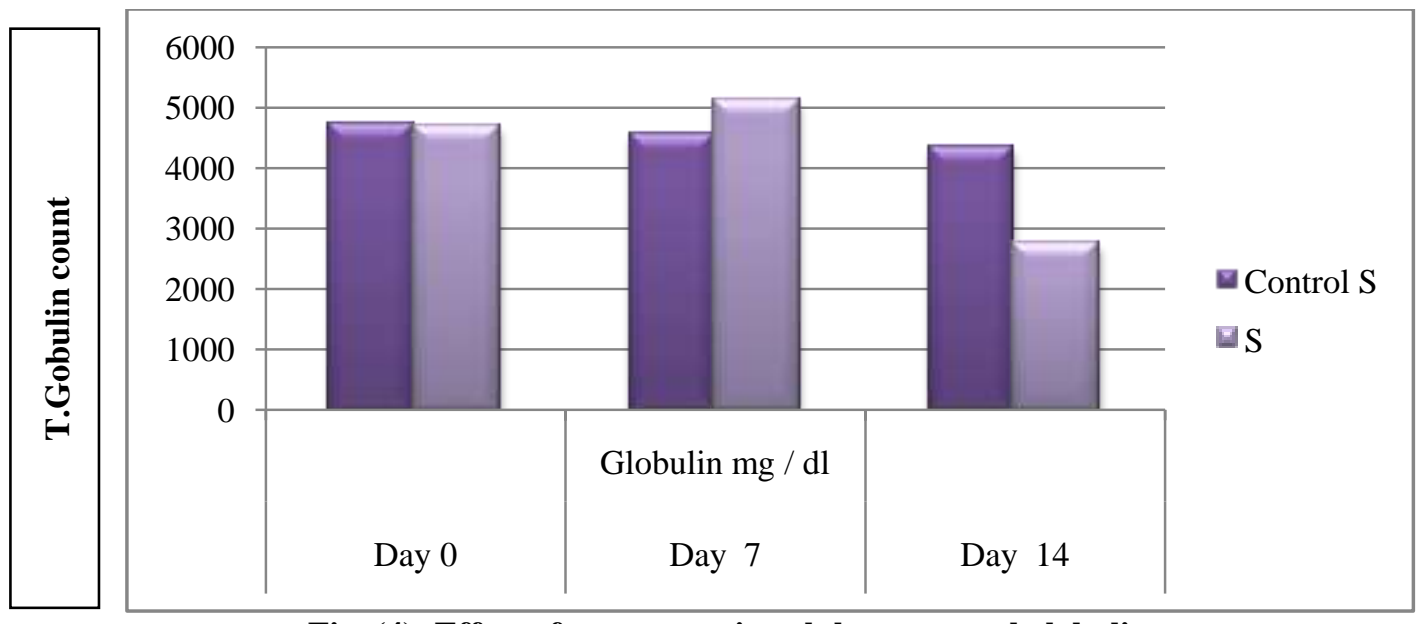

Fig. (4): Effect of streptomycin sulphate on total globulin. 
foreign organisms within short and long terms.

Data on the effect of streptomycin sulphate (s) on total globulin in comparison to the control (control s) at the $0,7^{\text {th }}$ and $14^{\text {th }}$ day (Fig. 4) show, an increase in total globulin at the $7^{\text {th }}$ day (short term), meaning that antibodies formation increased and was not affected by chloramphenicol sodium succinate so no effect on immune response. While a decrease in total globulin at the $14^{\text {th }}$ day (long term) means that, the antibodies formation was affected by chloramphenicol sodium succinate and thus the immune response decreased.

Moreover, streptomycin sulphate did not affect on total globulin in short term treatment but it affected the total globulin at long term treatment, that means it is not interfere with globulin at short term but suppress globulin at long term.

The present study recommends that the use of chloramphenicol sodium succinate and streptomycin sulphate needs an extreme caution because both of them show a high risk on the immune response of the body.

\section{REFERNCES}

Cannon D.C. (1974). Clinical Chemistry. Principle and Techniques, $2^{n d}$ Ed., p.411-421.

Chirigos M. A. (1992). Immunomodulators: current and future development and application. Thymus, 19:7-9.

Dale M. M., Foreman J.C. and Fan T.P.D. (1994). Introduction to the immunology and pathology of host defence mechanisms. Textbook of Immunopharmacology: Blackwell Scientific Publication, Oxford.p.1-3.

Dewdeny J. M. (1977). Immunology of the antibiotics. In: Sela M.Ed. The Antigens.New York Academic press. p.114122.

De Weck A.L. (1990). Drug allergy, immunotherapy, immune complexes and anaphylaxis. Curr. Opin. Immunol., 2:548557.

Doumas B.T.,Watson W. and Biggs H.G.(1971).
Albumin standard and the measurement of serum albumin with bromcresol green.Clin.Chim.Acta,31(1):87-96.

Iordanova A. I., Navashin P.S., Smolkina T.V., and Nikitin A.V. (1996). Effect of lomefloxacin on the synthesis of antibodies to vaccine $\mathrm{EV}$ fraction $\mathrm{I}$ and haemaglutinins. AntibiotKhimioter,41:4447.

Iordanova A.I., Smolkind T.V. and Nikitin A.V. (1995). Multifactor analysis of the action of norfloxacin on the humoral immune response. AntibiotKhimioter, 40:16-22.

Jayakumar K.,Honnegowda Krishnappa G., Sastry K.N.V. and Narayana K. ( 2002). Effect of ciprofloxacin on specific immune response in rabbits. Indian J. Exp. Biol., 40:111-114.

Killby V.A. and Silverman P.H. (1967). Toxicity of antibiotics in laboratory rodents. Science, 156- 164.

Mosteller R.D. ( 1987). Simplified Calculation of Body Surface Area. J. Med., 317(17):10981105.

Neu H.C. and Gootz, T.D. (1996). "Antimicrobial Chemotherapy:Antimicrobial Inhibitors of Ribosome Function". In Baron et al (1996). Baron's Medical Microbiology (4th Ed.). University of Texas Medical Branch. ISBN 0-9631172-1-1. PMID 21413283

Sharma D., Cukras A.R., Rogers E.J., Southworth D.R. and Green R. (2007). Mutational analysis of $\mathrm{S} 12$ protein and implications for the accuracy of decoding by the ribosome. J. Molecular Biology: p.110-111.

Sheng F.C., Frieschlag J, B., Backstrom B., Kelly D. and Busuttil R.W. (1987). The effect of in vivo antibiotics on neutrophil (PMN) activity in rabbits with peritonitis. J. Surg. Res.,43:239-251.

Weber D.K., Danielson K., Wright S. and Foley J.E. (2002). Hematology and serum biochemistry values of dusky-footed wood rat (Neotomafuuscipes). J. Wildlife Diseases, 38(3): 576-582. 


\section{تأثيرسلفات الاستريبتوميسين والكلور|مفينيكول صوديوم سكسينات على الاستجابة المناعية \\ محمل زكريا صديق - وليد ضياء الدين صالح - سيد عبد القادر سيد- محم حسن محمد

$$
\text { قسم الميكروبيولوجيا- كلية الزراعة - جامعة القاهرة - الجيزة- مصر }
$$

بعتبر كلا من الاستربتوميسين والكلور امفينيكول من المضادات الحيوية كثيرة الاستخدام ويُصنّف الاستربتوميسين كأول

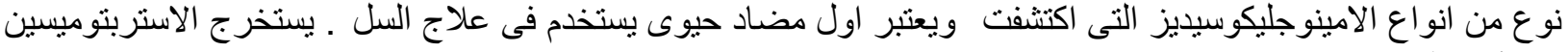

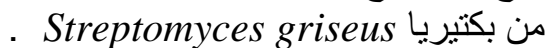
أما الكلور امفينيكول فيستخرج من بكتريا Streptomyces venezuelae ويعتبر من المضادات الحيوية واسعة المجال

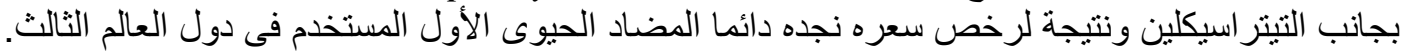

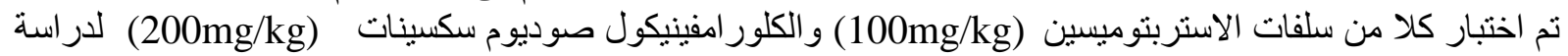

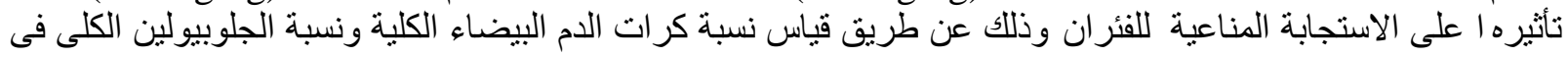

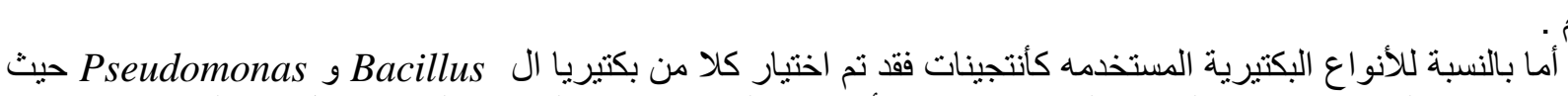

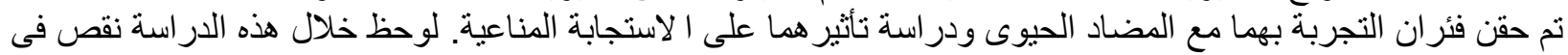

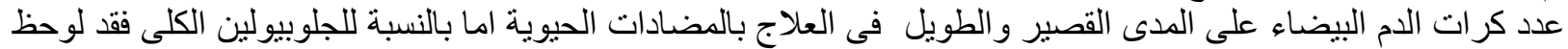

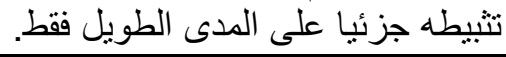

